International Journal of Food and Nutrition Research
(ISSN:2572-8784)

\title{
Changes in Microbiological Quality of Table Spreads Produced from African Pear (Dacryodes edulis) Pulp during Storage
}

\author{
Akusu, Ohwesiri Monday*; Wordu, Gabriel Oji and Obiesie Chidiebere
}

Department of Food Science and Technology, Rivers State University, Nkpolu Oroworukwo, P. M. B., 5080, Port Harcourt, Nigeria

\begin{abstract}
African pear (Dacryodes edulis) pulp was extracted and pasteurized. The pasteurized pulp was homogenized with $A$ different levels of food grade additives to form table spreads of samples $A$ to $H$ while sample I was left without preservative. The spreads were packed in sealed glass containers and stored at room temperature $(28 \pm 20 \mathrm{C})$ for 4 weeks to evaluate the changes in microbiological quality of table spread during storage period. Samples were collected in a weekly interval to study the microbiological assay of the spread starting from week zero to the last week. High total bacteria count of $1.8 \times 107$ CFU/ $\mathrm{ml}$ was seen in sample I (spread without preservative) at week zero, this increased significantly to $8.1 \times 108 \mathrm{CFU} / \mathrm{ml}$ after 3 weeks of storage and TNTC (too numerous to count) after 4 weeks of storage at $28 \pm 20 \mathrm{C}$. The least growth were observed in samples $A$ and $C$ with bacteria counts of $8.1 \times 107 C F U / m l$ and $3.5 \times 107 C F U /$ $\mathrm{ml}$, respectively. The least fungi count of $2.0 \times 106 \mathrm{CFU} / \mathrm{ml}$ was noted in sample $C$ after 4 weeks of storage while the highest fungi count of $4.5 \times 107 \mathrm{CFU} / \mathrm{ml}$ was seen in sample I after 4 weeks of storage at room temperature $(28 \pm 20 \mathrm{C})$. The suspected microorganisms based on their morphology were; E. coli, Staphylococcus aureus, Salmonella specie while fungi were Penicillium specie and Aspergillus specie. Deterioration sets in significantly after two weeks storage as total bacteria and fungi counts rose above $1.0 \times 107$ and 1.5x106, respectively. The microbiological quality of the samples was stable up to the second week of storage except sample I (without preservative).
\end{abstract}

Keywords: Microbiological Quality, Vegetable Spreads, African Pear Pulp, Storage Temperature, Nutritional Quality, Preservatives
*Correspondence to Author: Akusu, Ohwesiri Monday

Department of Food Science and Technology, Rivers State University, Nkpolu Oroworukwo, P. M. B., 5080, Port Harcourt, Nigeria

How to cite this article:

Akusu O. M, Wordu G. O and Obiesie C. Changes in Microbiological Quality of Table Spreads Produced from Af-rican Pear (Dacryodes edulis) Pulp during Storage. International Journal of Food and Nutrition Research, 2019; 3:20.

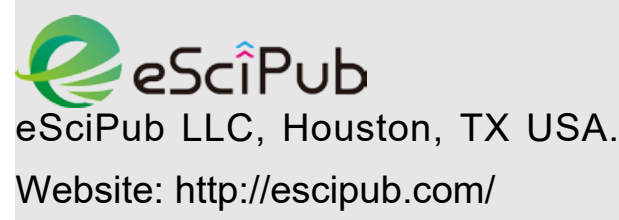




\section{Introduction}

Food preservation is the science of extending the shelf life of food, maintaining its nutritional quality and avoiding the growth of unwanted microorganisms [1]. It is the process of treating and handling food to stop or slow spoilage which results to loss of quality, edibility or nutritional values and thus allow for longer storage. Preservation involves preventing the growth of bacteria, yeast, fungi and other microorganisms [2]. Vegetable spreads are spreadable product having at least $90 \%$ ingredients from nuts and pulps used in various forms, such as paste and slurry $[3,4]$. Vegetable spreads are used like the commercially available butter, they can be produced from almond, cashew, hazelnut, macadamia nut, peanut, pecan, pistachio and walnut [5]. Vegetable spread is popular and widely accepted by consumers due to its flavour, good nutritional values and suitability for consumption either alone or in combination with a variety of other foods. African pear pulp has great potential for vegetable spread production. The African pear tree (Dacryodes edulis) is a tropical oleiferous fruit tree that possesses enormous potential in Africa [6]. Various parts of the tree are used in traditional medicine[7,8]. The wood serves for firewood and carpentry [9]. The entire tree is used in Agro-forestry systems for soil conservation [10]. Dacryodes edulis fruit is popular in the diets of many Africans. It can be eaten raw, roasted or boiled in hot water and is eaten alone or used in garnishing cooked or roasted maize. It could also be used as butter to eat bread [8]. It has been found in Cameroon recipe that when the pulp of African pear is cooked and seasoned, it serves as spread [11]). According to Ayuku et al.[12], D. edulis has a potential to improve nutrition and food security. During the last three decades, more and more studies have been conducted on $D$. edulis, essentially the tree and its fruit. The scientific researches on $D$. edulis focused on the characterisation of propagation techniques of $D$. edulis tree [13], the nutritive value of its pulp and its oil [14] and the oil extraction processes[15]. These studies revealed excellent nutritional qualities of fruit pulp and interesting food processing properties of the oils extracted from the pulp and kernel safou [16]. These have also revealed the importance of this fruit nutritionally, therapeutically and in cosmetics. The pulp, the only edible part of the fruit is particularly rich in lipids, hence, it could be an important source of oil [17]. Besides lipids, $D$. edulis pulp contains substantial amount of many other nutrients including proteins, carbohydrates, minerals, vitamins and fibres[16]).

High content of protein and other essential nutrients in African pear spread makes it susceptible to microbiological contamination and growth. Thus, the objective of this work was to produce table spreads from African pear pulp treated with different levels of preservatives and to evaluate the effect of room temperature $\left(28 \pm 2^{\circ} \mathrm{C}\right)$ storage on the microbiological quality of the product.

\section{Materials and Method}

\subsection{Materials}

Mature and good quality fruits of the African pear (Dacryodes edulis) were purchased from the fruit market in Port Harcourt and transferred to the Microbiological Laboratory in the Department of Food Science and Technology, Rivers State University, Port Harcourt, Nigeria. All apparatus and chemicals used for the study were obtained from the same Laboratory and were of analytical grade.

\subsection{Extraction of African Pear Pulp and the Formulation of the Spread}

The pulp was extracted using modified traditional method of pear roasting. African pear fruits were sorted and washed with tap water and sodium chloride solution, furthermore rinsed thoroughly. They were roasted at $60^{\circ} \mathrm{C}$ for $4 \mathrm{~min}$ in a hot air oven (model QUB 305010G, Gallenkamp, UK). The roasted fruits were allowed to cool for $10 \mathrm{~min}$, the thin bluishblack epicarp were gently removed and 
discarded while the soft pulps were scraped off The mixture was homogenized properly using a and recovered in sterile stainless steel plates. laboratory stirrer (model JKL 2145, REMI The extracted pulp was pasteurized by heating Motors, India) to produce the African pear at $100^{\circ} \mathrm{C}$ for $5 \mathrm{~min}$ in a stainless pot. The spread (APS) as presented in Figure 1 and pasteurized pear pulp was treated with different Table 1.

levels of recommended food preservatives [18].

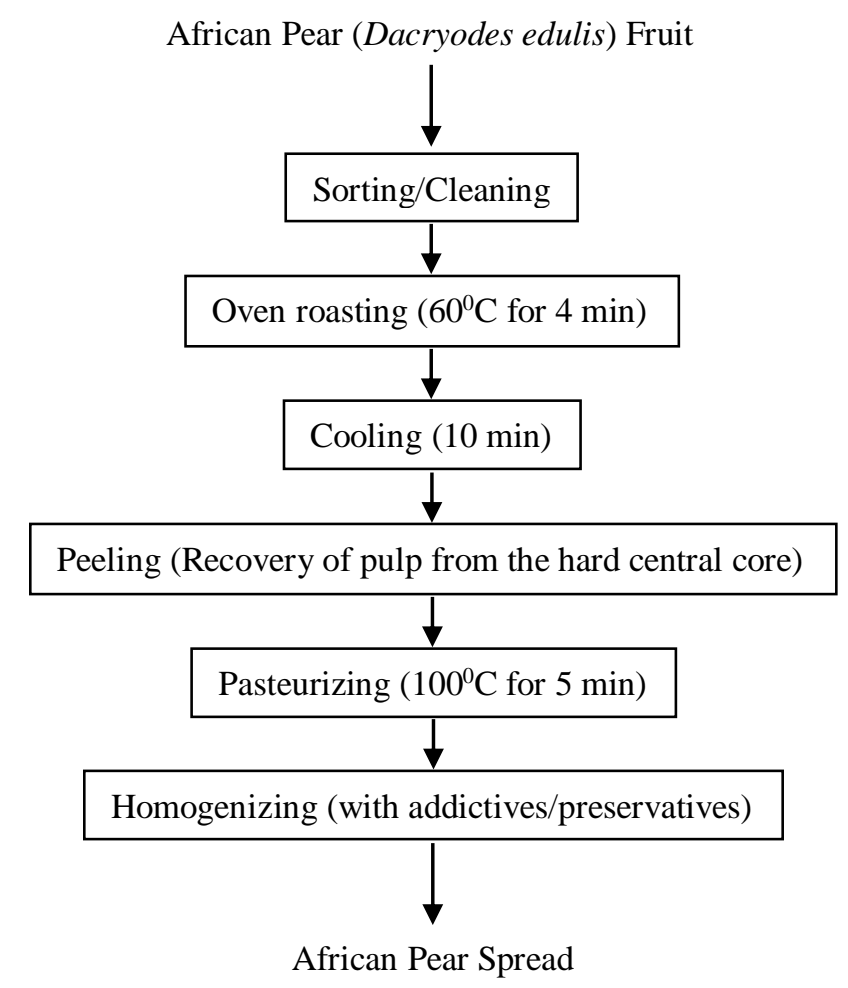

Figure1. Flow Chart for the Production of African Pear Spread

Table 1. African Pear Spread (APS) Formulations

\begin{tabular}{cccccc}
\hline SAMPLES & PEAR PULP & $\mathbf{H}_{2} \mathbf{O}$ & $\mathbf{P S}$ (E200) & BHT (E321) & CA (E330) \\
\hline & $\mathbf{( g )}$ & $\mathbf{( g )}$ & $\mathbf{( g )}$ & $\mathbf{( g )}$ & $\mathbf{( g )}$ \\
A & 100 & 15 & 0.045 & & \\
B & 100 & 15 & 0.035 & & \\
C & 100 & 15 & & 0.01 & \\
D & 100 & 15 & & 0.005 & \\
E & 100 & 15 & & & 0.008 \\
F & 100 & 15 & & & 0.005 \\
G & 100 & 15 & 0.025 & 0.005 & \\
H & 100 & 15 & & 0.005 & 0.008 \\
I & 100 & 15 & & & \\
\hline
\end{tabular}

Key: PS = Potassium sorbate, $\mathrm{BHT}=$ Butylated hydroxytoluen, $\mathrm{CA}=$ Citric acid.

\subsection{Storage of Samples}

The produced spreads were stored in sealed glass containers at room temperature $\left(28 \pm 2^{\circ} \mathrm{C}\right)$. Samples were collected at one-week interval for a period of four weeks for storage studies from week one, two, three and four using week zero as the control sample.

\subsection{Microbiological Analysis}

Storage stability of the spreads were conducted to study the changes in microbiological quality which included; total bacterial count, total fungi 
count and an assay of the microorganisms associated with the spoilage of African pear spreads dusring storage.

\subsubsection{Total Bacteria and Fungi Count}

Microbial assay was carried out on each of the stored spread samples to test the presence of bacteria and fungi using nutrient agar (NA) and potato dextrose agar (PDA) for total bacteria and fungi counts, respectively. The procedure described by the International Commission on Microbiological Specification for Food [19] was adopted in this study.

\subsubsection{Sterilization of Materials}

All glassware used were sterilized by autoclaving at $121^{\circ} \mathrm{C}$ for $15 \mathrm{~min}$ and allowed to cool before use.

\subsubsection{Culture Media Preparation}

The powder media were weighed and dissolved in distilled water in accordance to each dilution factor as follows: NA: $28 \mathrm{~g}$ powder in $1000 \mathrm{ml}$ distilled water to obtain $2.8 \%(\mathrm{w} / \mathrm{v})$ solution. PDA: $39 \mathrm{~g}$ powder in $1000 \mathrm{ml}$ distilled water to obtain $3.9 \%(w / v)$ solution. The mixtures were stirred separately, properly and sterilized at $121^{\circ} \mathrm{C}$ for $15 \mathrm{~min}$ in an autoclave. They were allowed to cool to $45^{\circ} \mathrm{C}$ and then dispensed into dishes using the spread-plate technique.

For diluents' preparation, one tablet of phosphate buffer was dissolved in $100 \mathrm{ml}$ of distilled water. Using a $10 \mathrm{ml}$ syringe, $9 \mathrm{ml}$ each of the buffer solution were injected into five (5) separate test tubes. Each of the tubes were covered with cotton wool and aluminium foil and then, sterilized at $121^{\circ} \mathrm{C}$ for $15 \mathrm{~min}$ in the Autoclave.

\subsubsection{Serial Dilution and Inoculation}

The spread sample was weighed (1g) and suspended in the first test tube (containing $9 \mathrm{ml}$ diluents), making the solution $10 \mathrm{ml}$. Serial dilution was done; by pipetting $1 \mathrm{ml}$ from the primary suspension $\left(10^{-1}\right)$ into the next tube $\left(10^{-2}\right), 1 \mathrm{ml}$ from that $2^{\text {nd }}$ tube into the next, the process continued to the last (fifth) tube. One $\mathrm{ml}$ from the last tube was removed and discarded. Prepared plates were inoculated using the spread plate (surface plating) method. The five tubes $\left(10^{-5}\right)$ were used for inoculation. From each of these tubes, $0.1 \mathrm{ml}$ was pipette onto the surface of an agar plate and spread evenly using a sterile L-shaped glass spreader. The plates were incubated at $35^{\circ} \mathrm{C}$ for $24-48$ $\mathrm{hr}$ for NA and $30^{\circ} \mathrm{C}$ for $96 \mathrm{hr}$ for PDA. The colonies were counted using a colony counter and result recorded as colony forming unit per $\mathrm{ml}(\mathrm{CFU} / \mathrm{ml})$.

\subsubsection{Isolation and Identification of Microorganisms Associated with the Spoilage}

This was done through sub-culture to obtain pure culture of isolates. Single colony of bacteria was randomly isolated from the mother culture onto a fresh prepared nutrient agar plate. It was inoculated using streak method and incubated at $37^{\circ} \mathrm{C}$ for $24 \mathrm{hr}$ for proper identification.

\subsubsection{Gram Staining}

A loop full of fresh culture was isolated and emulsified in a drop of distilled water and allowed to air-dry. The film was heat-fixed by passing it over a flame for $3 \mathrm{sec}$ before covering with crystal violet for $60 \mathrm{sec}$. It was rinsed with running tap water, drained and covered with iodine for $60 \mathrm{sec}$, rinsed again with water and decolorized with ethanol for 30 $\mathrm{sec}$, counterstained with safrain for $60 \mathrm{sec}$ after rinsing off the ethanol. The film was rinsed finally and air-dried before viewing under the microscope.

\subsubsection{Identification of Isolates}

The following characteristics were used for identification of the isolates: size of colony, shape, edge, elevation, pigmentation, texture, opacity, consistency and odour of colony.

\subsubsection{Biochemical Test}

The following biochemical test were done for identification and confirmation of the isolates: indole test, motility, oxidase, catalase, methyl red and voges proskeur test.

\section{Results and Discussion}

3.1. Total Bacteria and Fungi Counts

IJFNR: http://escipub.com/international-journal-of-food-nutrition-research/ 
As shown in Table 2, samples A, B, C and F did not show any bacteria growth at week zero. High total bacteria count of $1.8 \times 10^{7} \mathrm{CFU} / \mathrm{ml}$ was seen in sample I (spread without preservative) at week zero, this increased significantly to $8.1 \times 10^{8} \mathrm{CFU} / \mathrm{ml}$ after 3 weeks of storage and TNTC (too numerous to count) after 4 weeks of storage at $28 \pm 2^{\circ} \mathrm{C}$. The least growth at week 4 were recorded in samples $A$ and $C$ with bacteria counts of $8.1 \times 10^{7} \mathrm{CFU} / \mathrm{ml}$ and $3.5 \times 10^{7} \mathrm{CFU} / \mathrm{ml}$, respectively.

Fungal growth was not observed in all the samples at week zero. Also Samples $C$ and $F$ also showed no growth at week 1 as presented in Table 3. The least fungi count of $2.0 \times 10^{6} \mathrm{CFU} / \mathrm{ml}$ was noted in sample $\mathrm{C}$ while the highest fungi count of $4.5 \times 10^{7} \mathrm{CFU} / \mathrm{ml}$ was observed in sample I after 4 weeks of storage period at room temperature $\left(28 \pm 2^{\circ} \mathrm{C}\right)$. This implies that BHT preservative was effective in subduing the bacterial and fungal growth in the produced pear spread. The total plate count of all the spread samples were beyond the marginal acceptable count of $5.0 \times 10^{6} \mathrm{CFU} / \mathrm{ml}$, for table spreads and margarine [19].

Table 2. Total Bacteria Counts $(\mathrm{CFU} / \mathrm{ml})$ on APS Treated with Different Levels of Preservatives during Storage

\begin{tabular}{llllll}
\hline Samples & \multicolumn{5}{c}{ Storage Time (Weeks) } \\
& $\mathbf{0}$ & $\mathbf{1}$ & $\mathbf{2}$ & $\mathbf{3}$ & $\mathbf{4}$ \\
\hline $\mathrm{A}$ & $\mathrm{NG}$ & $1.6 \times 10^{6}$ & $1.9 \times 10^{7}$ & $3.5 \times 10^{7}$ & $8.1 \times 10^{7}$ \\
$\mathrm{~B}$ & $\mathrm{NG}$ & $1.0 \times 10^{6}$ & $1.6 \times 10^{7}$ & $3.3 \times 10^{7}$ & $1.0 \times 10^{8}$ \\
$\mathrm{C}$ & $\mathrm{NG}$ & $1.0 \times 10^{6}$ & $3.0 \times 10^{6}$ & $1.0 \times 10^{7}$ & $3.5 \times 10^{7}$ \\
$\mathrm{D}$ & $6.0 \times 10^{6}$ & $2.8 \times 10^{7}$ & $4.6 \times 10^{7}$ & $2.0 \times 10^{8}$ & $6.1 \times 10^{8}$ \\
$\mathrm{E}$ & $1.2 \times 10^{6}$ & $1.0 \times 10^{7}$ & $4.9 \times 10^{7}$ & $8.0 \times 10^{7}$ & $1.7 \times 10^{8}$ \\
$\mathrm{~F}$ & $\mathrm{NG}$ & $2.0 \times 10^{6}$ & $5.6 \times 10^{6}$ & $1.2 \times 10^{7}$ & $1.0 \times 10^{8}$ \\
$\mathrm{G}$ & $1.0 \times 10^{6}$ & $6.0 \times 10^{\mathrm{b}}$ & $2.9 \times 10^{7}$ & $1.1 \times 10^{8}$ & $2.0 \times 10^{8}$ \\
$\mathrm{H}$ & $3.0 \times 10^{6}$ & $1.9 \times 10^{7}$ & $2.9 \times 10^{7}$ & $8.1 \times 10^{7}$ & $1.5 \times 10^{8}$ \\
$\mathrm{I}$ & $1.8 \times 10^{7}$ & $4.7 \times 10^{7}$ & $8.9 \times 10^{7}$ & $8.1 \times 10^{8}$ & TNTC \\
\hline
\end{tabular}

Table 3. Total Fungi Counts (CFU/ml) on APS Treated with Different Levels of Preservatives during Storage

\begin{tabular}{|c|c|c|c|c|c|}
\hline \multirow[t]{2}{*}{ Samples } & \multicolumn{5}{|c|}{ Storage Time (Weeks) } \\
\hline & 0 & 1 & 2 & 3 & 4 \\
\hline A & $N G$ & $2.0 \times 10^{6}$ & $2.0 \times 10^{6}$ & $3.0 \times 10^{6}$ & $3.5 \times 10^{6}$ \\
\hline B & $N G$ & $1.1 \times 10^{6}$ & $2.0 \times 10^{6}$ & $2.8 \times 10^{6}$ & $3.0 \times 10^{6}$ \\
\hline C & $N G$ & $N G$ & $1.0 \times 10^{6}$ & $1.5 \times 10^{6}$ & $2.0 \times 10^{6}$ \\
\hline D & $N G$ & $1.0 \times 10^{6}$ & $1.0 \times 10^{6}$ & $2.0 \times 10^{6}$ & $1.1 \times 10^{7}$ \\
\hline E & $N G$ & $2.0 \times 10^{6}$ & $2.0 \times 10^{6}$ & $8.0 \times 10^{6}$ & $1.7 \times 10^{7}$ \\
\hline $\mathrm{F}$ & $N G$ & $N G$ & $1.0 \times 10^{6}$ & $2.0 \times 10^{6}$ & $3.0 \times 10^{6}$ \\
\hline G & $N G$ & $2.0 \times 10^{6}$ & $3.0 \times 10^{6}$ & $8.0 \times 10^{6}$ & $1.4 \times 10^{7}$ \\
\hline $\mathrm{H}$ & $N G$ & $1.0 \times 10^{6}$ & $1.1 \times 10^{6}$ & $2.0 \times 10^{6}$ & $1.0 \times 10^{7}$ \\
\hline I & $N G$ & $2.0 \times 10^{6}$ & $2.0 \times 10^{6}$ & $1.7 \times 10^{7}$ & $4.5 \times 10^{7}$ \\
\hline
\end{tabular}

Key: APS $=$ African pear spread; $A=$ APS treated with potassium sorbate $(0.045 \%) ; B=$ APS treated with potassium sorbate $(0.035 \%) ; \mathrm{C}=$ APS treated with BHT $(0.01 \%) ; \mathrm{D}=\mathrm{APS}$ treated with BHT $(0.005 \%) ; \mathrm{E}=$ APS treated with citric acid $(0.008 \%) ; \mathrm{F}=$ APS treated with citric acid $(0.005 \%) ; G=$ APS treated with BHT $(0.005 \%)$ and potassium sorbate $(0.025 \%) ; \mathrm{H}=$ APS treated with citric acid $(0.008 \%)$ and $\mathrm{BHT}(0.005 \%) ; \mathrm{I}=\mathrm{APS}$ without preservative; $\mathrm{NG}=$ no growth; TNTC = too numerous to count 


\subsection{Microorganisms \\ Associated \\ with Spoilage of APS and their Biochemical Reactions}

The suspected microorganisms based on their morphology were; E. coli which was Gram negative (-), VP negative (-), Ind negative (-), MR negative (-), OX negative (-), with positive $(+)$ motility as shown in Table 4. Staphylococcus aureus which was Gram positive (+), VP negative (-), Ind negative (-),
OX positive (+) and catalase positive (+). Salmonella specie which was Gram negative (), VP negative (-), Ind negative (-), OX negative $(-)$ with positive $(+)$ motility. Penicillium specie which its colonies grew in shades of green with broom-like head. Aspergillus specie, its colonies also grew in shades of yellowish-green with swollen vesicle and flasked-shaped phialides.

Table 4. Microorganisms Associated with Spoilage of APS and their Biochemical Reactions

\begin{tabular}{llllllll}
\hline Suspected Organism & $\begin{array}{l}\text { Gram } \\
\text { RXN }\end{array}$ & VP & Ind. & MR & Motility & OX & Catalase \\
\hline E. Coli & - & - & - & & + & - &. \\
Staph. Aureus & + & - & - & & & + & + \\
Salinonella sp & - & - & - & & + & - & \\
\hline
\end{tabular}

Key: $\mathrm{VP}=$ voges proskeur, Ind = Indole, $\mathrm{MR}=$ methyl red, $\mathrm{OX}=$ oxidase,

\section{Conclusion}

The findings from this work showed that table spreads produced from African pear pulp and treated with $0.010 \%$ BHT preserved better than citric acid and potassium sorbate. The least bacteria counts were observed in samples $A$ and $C$. In terms of fungi, least and highest counts were recorded in samples $C$ and I, respectively after 4 weeks of storage period at room temperature $\left(28 \pm 2^{\circ} \mathrm{C}\right)$. The microbiological quality of the table spreads treated with food grade preservatives was stable up to the second week of storage. The need to review the treatment content with cognisance to good manufacturing practice (GMP) is highly recommended.

\section{References}

1. Rahman SM (2007). Hand Book of Food Preservation. $2^{\text {nd }}$ Edn. London. Taylor and Francis Group.

2. FAO (2005). Food and Agriculture Organization of the United Nations. Principles and practices of small- and medium-scale fruit juice processing. Available:http://www.fao.org/docrep/005/y2 515e/y2515e09.htm

3. USDA (2006). United States Department of Agriculture. Commercial Item Description.
Peanut Butter; United State Department of Agriculture, Washington, DC, USA.

4. Nielsen SS (2010). Food Analysis; Springer: New York, NY, USA.

5. Mangels R (2001). Guide to nuts and nut butters. Vegetarian Journal, 21, 20-23.

6. Kengué J (1990). Le Safoutier (Dacryodes edulis (G.Don) H.J.Lam), premières données sur la morphologie et la biologie. Thèse de doctorat, Université de Yaoundé, Cameroun.

7. Okafor JC (1983). Varietal delimitation in Dacryodes edulis (G.Don) H.J.lam (Burseraceae). International Tree Crops Journal, 2, 255-265.

8. Duru M, Amadi C, Ugbogu A, Eze A and Amadi B (2012). Phytochemical, vitamin and proximate composition of Dacryodes edulis fruit at different stages of maturation. Asian Journal of Plant Science and Research, 2(4), 437-441.

9. Ndoye O, Ruiz-Pérez M and Eyebe A (1997). The Markets of Non-Timber Forest Products in the Humid Forest Zone of Cameroon. ODI Rural Development Forestry Network Paper, Yaounde, Cameroon.

10. Ndangang V (1989). A Survey of Traditional Agro-Forestry Woody Plants of the North-West Province of Cameroon. Pre-Optional

Study Report, National Advance School, Agriculture, Yaounde, Cameroon, p. 72.

11. Kadji BRL, Kone FMT, Sika AE and Dabonne SI (2016). Physico-chemical properties of Safou 
(Dacryodes edulis) fruits grown in Côte d'Ivoire. Journal of Applied Biosciences, 105, 1010310110.

12. Ayuku ET, Duguma B, Kengue J, Tiki-managa T and Zekkeng $P$ (2000). Uses, management and economic potential of Dacryodes edulis in human low-land Cameroon. Economic Botany, 53(3), 292-300.

13. Kengué J (2002). Fruits for the Future 3. Safou: Dacryodes edulis. Research for Development in Department for International Development. p. 147.

14. Ajayi IA, Oderinde RA, Kajogbola DO and Uponi $\mathrm{JI}$ (2006). Oil content and fatty acid composition of some underutilized legumes from Nigeria. Food Chemistry, 99(1), 115-120.

15. Kapseu C (2009). Production, analyse et applications des huiles végétales en Afrique. Oleagineux Corps Gras, Lipides, 16(4), 215-229.

16. Poligui RN, Mouaragadja I, Haubruge E and Francis F. (2013). La culture du safoutier (Dacryodes edulis (G. Don) H.J.Lam (Burseraceae)): enjeux et perspectives de valorisation au Gabon (synthèse bibliographique). Biotechnologie Agronomie société et Environnement, 17(1), 131-147.

17. Ondo-Azi A, Ella Missang $M$, Silou $T$ and Chalchat $J$ (2013). Variation in Physicochemical Characteristics of Safou (Dacryodes edulis (G. Don) H.J. Lam) fruits.

18. CODEX-STAN (1999). CODEX Alimentairus Commission Standard for Named Vegetable Oils, FAO Corporate Document, CODEX STAN 210. Retrieved from https://www.fao.org/docrep/004/y2774e05. 5th July, 2016.

19. ICMSF (1995). International Commission On Microbiological Specification for Foods. Food Administration Manual. Version 2.0. Retrieved from http://www.icmsf.org. 3rd July, 2017). 